\title{
AN ANALYSIS OF CHALLENGES AND BARRIERS IN IMPLEMENTING BASEL III IN THE LICENSED COMMERCIAL BANKS OF SRI LANKA
}

By

THUSHANI WATHHSAILAAHEWA WITHARANA 


\title{
AN ANALYSIS OF CHALLENGES AND BARRIERS IN
}

\section{IMPLEMENTING BASEL III IN THE LICENSED}

COMMERCIAL BANKS OF SRI LANKA

\author{
By \\ THUSHANI WATHSALA HEWAWITHARANA
}

A research submitted to the University of Sri Jayewardenepura in partial fulfillment of the requirements for the degree of Master of Business Administration in Management (Finance) in January 2016 
The work described in this research was carried out by me under the supervision of Professor Kennedy D. Gunawardana and a report on this has not been submitted in whole or in part to any university or any other institution for another

Degree/Diploma

Signature:

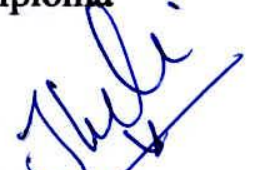

Name of Candidate: Thushani Wathsala Hewawitharana

Date: $25^{\text {th }}$ June 2016 
"I certify that the above statement made by the candidate is true and that this research project is suitable for submission to the University for the purpose of evaluation."

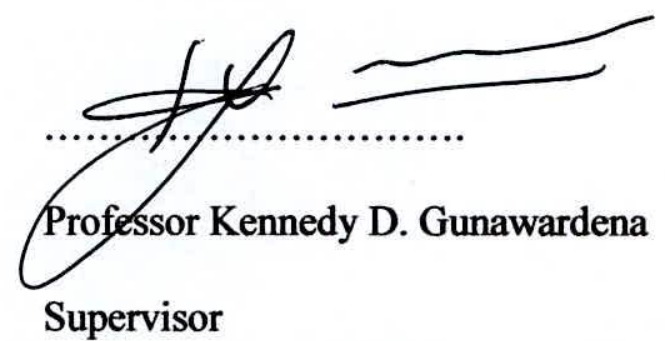

Date: $25^{\text {th }}$ June 2016

Supervisor

Prof. Dr. Kennedy D. Gunawardana

B.Sc(SJP), MBA(Col), PhD(Abac), CMA(Au)

Professor of Accounting

Department of Accounting

University of Sri Jayewardenepura

Nugegoda

Sri Lanka. 


\section{ACKNOWLEDGEMENT}

My sincere gratitude goes to:

Professor Kennedy D. Gunawardena - my supervisor and lecturer for his invaluable support and guidance during the entire tenure of the Master of Business Administration program and especially during the dissertation by checking my progress and pointing out the areas for improvement which allowed me to do justice to my research.

Dr. Janak Kumarasinghe - the coordinator of the Master of Business Administration program for making it possible for me to conduct this study by providing me with assistance, guidance and encouragement at all times.

Faculty of Management Studies and Commerce - all lectures and staff of the Faculty of Management Studies and Commerce, University of Sri Jayewardenepura, for their support during my period of study.

Mr. Ranjith Hewawitharana and Mrs. Nanda Hewawitharana - my beloved parents, for their continuous support and constant encouragement for my studies from Childhood to the MBA.

Mr. Praveen Coorey - my husband, for the guidance, encouragement, support and the patience shown during this time of study. 


\section{TABLE OF CONTENTS}

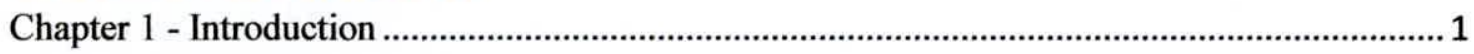

1.1 Background on the Research Topic........................................................................

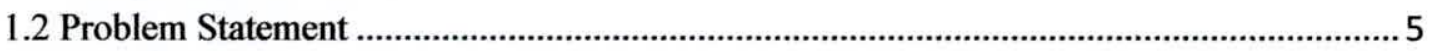

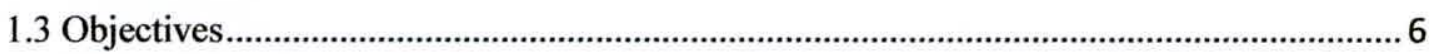

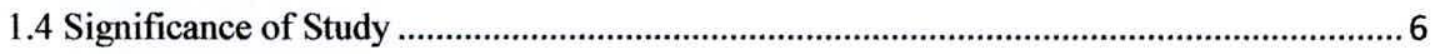

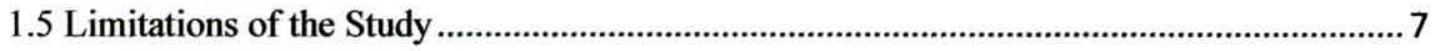

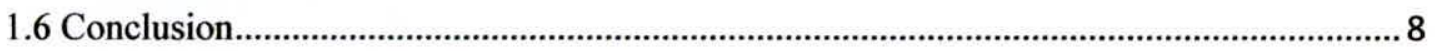

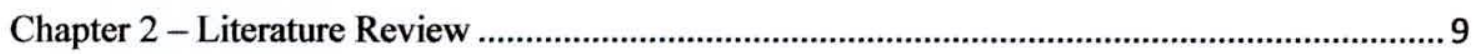

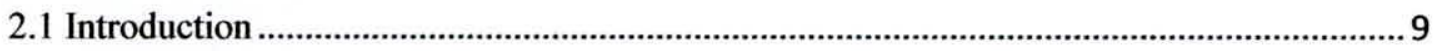

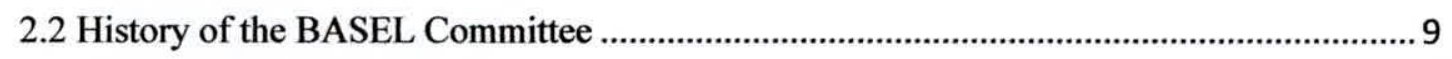

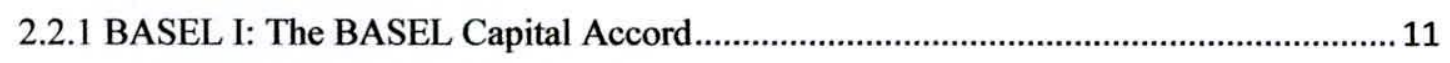

2.2.2 BASELII: The New Capital Framework .............................................................. 13

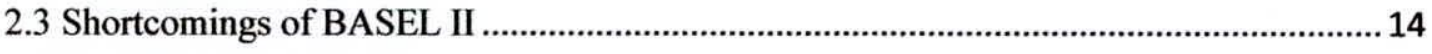

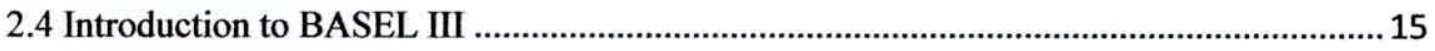

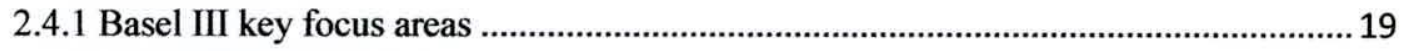

2.4.2 How Global Banks are responding to BASEL III ........................................................2 20

2.4.3 Key Changes in BASEL III in comparison to BASEL II..........................................22

2.4.4 The Key elements in BASEL III framework............................................................25

2.4.5Reporting and Disclosure Requirements..................................................................40

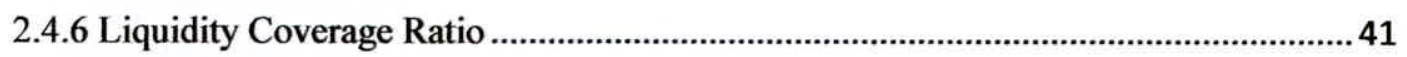

2.5BASEL III Implementation in a Sri Lankan Context.......................................................48

2.6 Implementation of Basel Accords and the Challenges and Barriers identified for Implementation - A Global Perspective ........................................................................... 51

2.6.1 United Arab Emirates (UAE) .................................................................................... 52

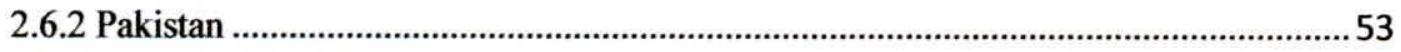

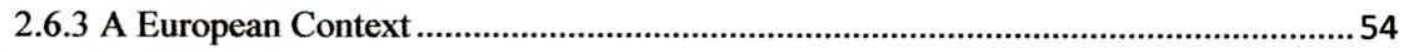

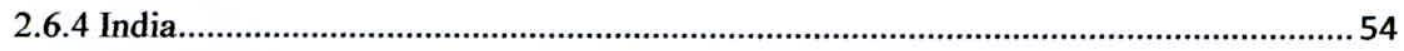

2.6.5 Latin America and the Caribbean...............................................................................5 


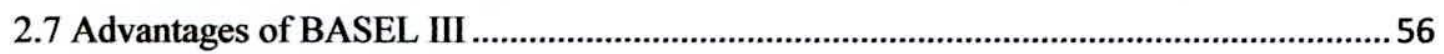

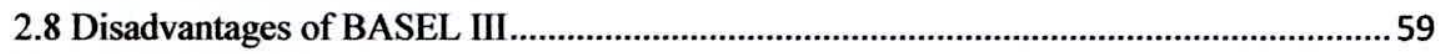

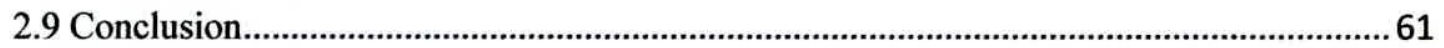

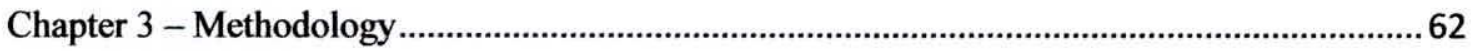

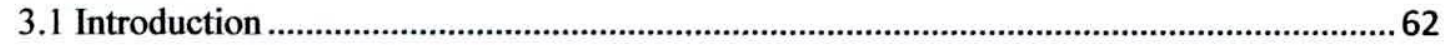

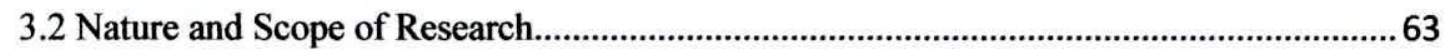

3.3 Brief Overview on Research Techniques......................................................................64

3.3.1 Primary Data Collection and the rationale for choosing a specific technique.............65

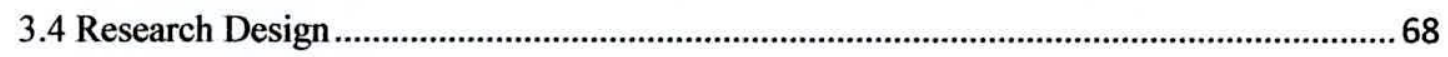

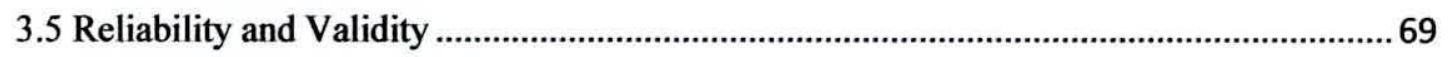

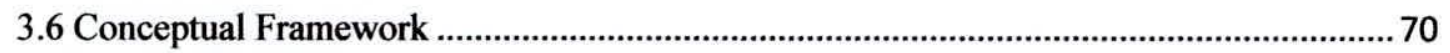

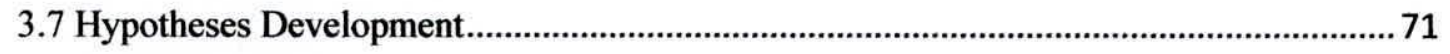

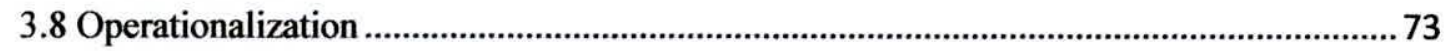

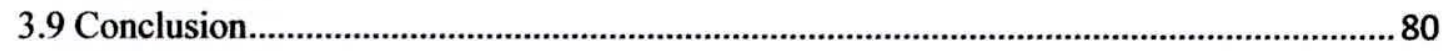

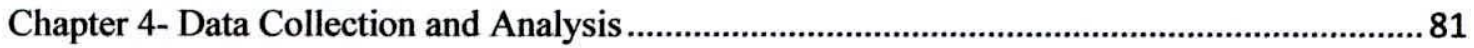

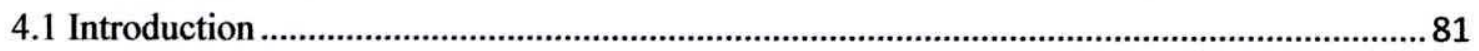

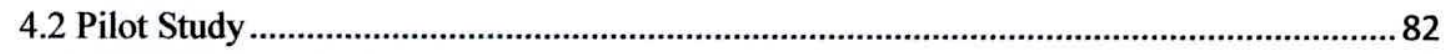

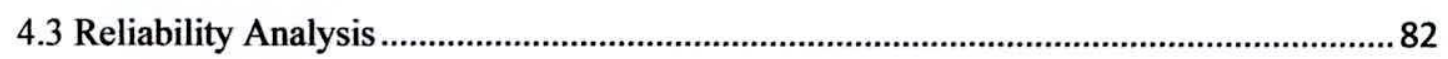

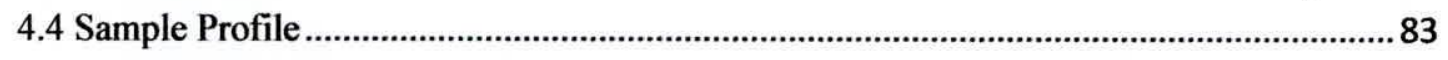

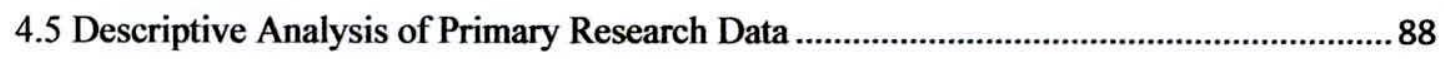

4.5.1 Variable: Level of Awareness on Basel III Accord...................................................... 88

4.5.2 Variable: Upgrades to IT Systems required for Implementation of Basel III ............. 90

4.5.3 Variable: Cost of Implementation of Basel III .......................................................... 91

4.5.4 Variable: Accounting and Regulatory Standards (Disclosure Practices) .................... 93

4.5.5 Variable: Human Resources and the Implementation of Basel III ..............................94

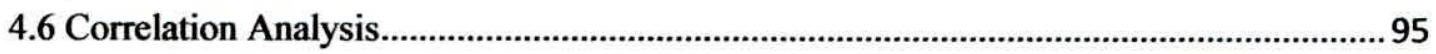

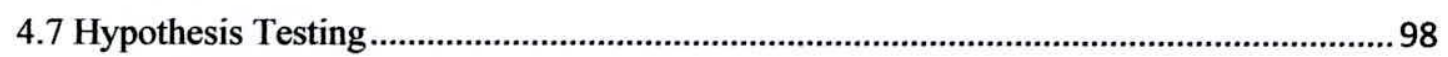

4.7.1 Hal; There is a relationship between the Level of Awareness and Successful

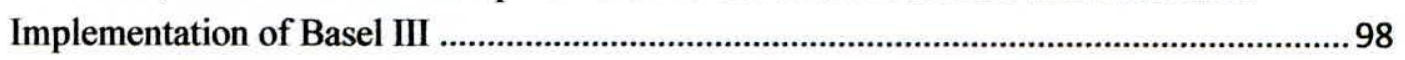

4.7.2 Ha2; There is a relationship between IT Systems and Successful Implementation of

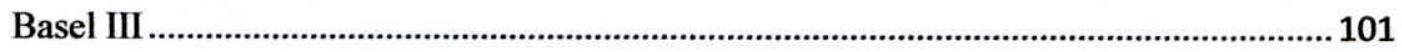

4.7.3 Ha3; There is a relationship between Cost and Successful Implementation of Basel III 
4.7.4 Ha4; There is a relationship between Accounting and Regulatory Standards

(Disclosure Practices) and Successful Implementation of Basel III.

4.7.5 Ha5; There is a relationship between Human Resources and Successful

Implementation of Basel III 110

4.7.6 Summary of the Hypotheses Analysis. 113

4.8 Analysis of Secondary Data Collected from Annual Reports of Banks operating in

Sri Lanka 115

4.8.1 Capital Adequacy and Liquidity Ratios among Sri Lankan LCB's 115

4.8.2 Tier 1 / Core Capital Requirements 116

4.8.3 Tier 2 / Total Capital Requirements . 120

4.8.4 Comparison of Liquidity Requirements under Basel II and Basel III 123

4.9 Conclusion 127

Chapter 5 - Discussion and Findings 128

5.1 Introduction 128

5.2 Key Findings from the Analysis of Primary Data 128

5.3 Key Findings from the Analysis of Secondary Data 134

5.4 Conclusion 136

Chapter 6 - Summary and Conclusion. 137

6.1 Introduction 137

6.2 Recommendations of the Study 138

6.3 Scope for Future Research 140

References 141

Annexure 151

Annex 1 - Basel III Transitional Phase 151

Annex II - Phase in Arrangement . 153

Annex III - Questionnaire used for Primary Data collection 157 


\section{LIST OF FIGURES}

Figure 2.1: Outlines of Basel II

Figure 2.2: Implementation Road Map 1 for Basel III in Sri Lanka

Figure 2.3: Implementation Road Map 2 for Basel III in Sri Lanka

Figure 3.1: The Conceptual Framework

Figure 4.1: Age Distribution of Questionnaire Respondents

Figure 4.2: Gender Distribution of Questionnaire Respondents

Figure 4.3: Education Level of Questionnaire Respondents

Figure 4.4: Hierarchy

Figure 4.5: Involvement in Basel III Implementation

Figure 4.6: Tier 1 or Core Capital Ratios of 8 Locally Owned Banks

Figure 4.7: Tier 1 or Core Capital Ratios of 6 Foreign banks Operating in Sri Lanka

Figure 4.8 - Tier 2 or Total Capital Ratios of 8 Locally Owned Banks

Figure 4.9 - Tier 2 or Total Capital Ratios of 6 Foreign Banks operating in Sri Lanka

Figure 4.10: Comparison of Liquidity Requirements under Basel II and Basel II 


\section{LIST OF TABLES}

Table 2.1 Key Focus Areas of Basel III

Table 2.2 Main Changes of Basel III identified by Ernst and Young

Table 2.3 Comparison between Basel II and Basel III

Table 2.4 The amortization schedule for Tier 02 capital instruments

Table 2.5 Phasing-out-arrangement of Additional Tier 01 /Tier 02 capital

Table 2.6 Banks Minimum Capital Conservation Standards for Common Equity Tier 01 Capital

Table 2.7 Banks Minimum Capital Conservation Standards for Total Capital

Table 2.8 The phased-in-arrangement for conservation buffer

Table 2.9 Description of High Quality Assets and Limitations

Table 2.10 Timelines for Liquidity Coverage Ratio

Table 3.1 The List of Hypothesis

Table 3.2 Operationalization Table

Table 4.1 Variable: Awareness on Basel III Accord

Table 4.2 Variable: Upgrades to IT Systems required for Implementation of Basel III

Table 4.3 Variable: Cost of Implementation of Basel III 
Table 4.4 Variable: Variable: Accounting and Regulatory Standards (Disclosure Practices)

Table 4.5 Variable: Human Resources and the Implementation of Basel III

Table 4.6 Correlation between the Independent Variables and Implementation of Basel III

Table 4.7 Model Summary - Level of Awareness and Successful Implementation of Basel III

Table 4.8 Anova Table - Level of Awareness and Successful Implementation of Basel III

Table 4.9 Coefficient Table - Level of Awareness and Successful Implementation of Basel III

Table 4.10 Model Summary - IT Systems and Successful Implementation of Basel III

Table 4.11 Anova Table - IT Systems and Successful Implementation of Basel III

Table 4.12 Coefficient Table - IT Systems and Successful Implementation of Basel III

Table 4.13 Model Summary - Cost and Successful Implementation of Basel III

Table 4.14 Anova Table - Cost and Successful Implementation of Basel III

Table 4.15 Coefficient Table - Cost and Successful Implementation of Basel III

Table 4.16 Model Summary - Accounting Standards and Successful Implementation of Basel III

Table 4.17 Anova Table - Accounting Standards and Successful Implementation of Basel III 
Table 4.18 Coefficient Table - Accounting Standards and Successful Implementation of Basel III

Table 4.19 Model Summary - Human Resources and Successful Implementation of Basel III

Table 4.20 Anova Table - Human Resources and Successful Implementation of Basel III

Table 4.21 Coefficient Table - Human Resources and Successful Implementation of Basel III

Table 4.22 Hypothesis Analysis

Table 4.23 Tier 1 or Core Capital Ratios of 8 Locally Owned Banks

Table 4.24 Tier 1 or Core Capital Ratios of 6 Foreign banks operating in Sri Lanka

Table 4.25 Tier 2 or Total Capital Ratios of 8 Locally Owned Banks

Table 4.26 Tier 2 or Total Capital Ratios of 6 Foreign Banks operating in Sri Lanka

Table 4.27 Comparison of Liquidity Requirements under Basel II and Basel II

Table 4.28 Capital Adequacy and Liquidity Coverage Hypothesis 


\title{
'AN ANALYSIS OF CHALLENGES AND BARRIERS IN IMPLEMENTING BASEL III IN THE LICENSED COMMERCIAL BANKS OF SRI LANKA,
}

By Thushani Wathsala Hewawitharana

\begin{abstract}
Since the early days of banking, it was identified that a uniform regulatory framework needs to be introduced to safeguard the global financial sector. With the exponential increase of international trade during the $2^{\text {nd }}$ half of the $20^{\text {th }}$ century, the need for international regulations for banking was more evident.
\end{abstract}

The Basel Accord has its origins in the financial turmoil of 1973. After the collapse of Bretton Woods's system of managed exchange rates, banks worldwide faced considerable foreign exchange losses which led to banking supervisors globally to formulate a regulatory framework for the banking sector.

As a result the Basel Committee of Banking Supervision formulated a minimum set of requirements for the operation of banks in 1988 and the G10 countries adopted this framework in 1992. This accord was heavily criticized in subsequent years for measuring risk only in terms of credit. This resulted in the introduction of Basel II which had a more wide angled approach to risks faced by the banking sector. However with the financial crisis that occurred in Western Countries in 2007; the need of putting forward a new accord to replace Basel II was identified. The Basel III was first 
introduced in 2010/11 and was modified in 2013. This accord gives emphasis to areas like Capital Adequacy, Stress Testing and Liquidity Coverage.

As the March 2019 deadline for Basel III compliance looms ever closer, banks across the globe including Sri Lanka race against the clock to meet the requirements outlined by Basel III. In this research the main barriers and challenges faced by Licensed Commercial Banks in Sri Lanka and their relationship for the successful implementation of Basel III will be identified. Further methods to overcome these barriers and challenges will be briefly discussed.

Primary and Secondary data were collected and analyzed using statistical and other methods to prove/disprove the objectives of the research. SPSS software was used for the statistical analysis of data. The outcome of the data was used to test the 6 Hypotheses developed in Chapter 3 of this research and the steps that can be taken to overcome these were briefly identified. 


\section{Chapter 1 - Introduction}

\subsection{Background on the Research Topic}

Business of Banking naturally entails assuming "Risks" in all business transactions. As a result, "Risk Management" remains to gain prominence as a key strategic focus in managing banks effectively in today's impulsive financial markets. The vision of Risk Management, as per Bertsch et al (2006), is to proactively assist the business in delivering superior shareholder value by ensuring an optimal trade-off between risks and rewards whilst upholding strong liquidity and adequate capital positions at all times combined with a robust asset quality.

The changing nature of today's business world is increasing the scope and potential impact of the risks faced. As per Schwerter (2011) ability of a bank to take strategic initiatives within pre-defined and consistent risk framework can be considered as a speciality that can make a distinction for a bank to ensure safety to all stakeholders in today's competitive market scenario. Hence, the Bank has recognised the risk management capabilities as a 'journey " rather than a destination and is committed to maintain and continuously improve its risk management framework and capabilities through a number of initiatives including substantial investments in IT, training and development of human resources.

As explained in NDB Bank PLC, Annual Report (2013) "Risk Management" can be divided into three major categorise as Credit, Market and Operational risk. Credit risk is the risk of financial loss if a customer or counterparty to a financial instrument fails to 